\title{
СУЧАСНІ РЕАЛІЇ ГЕПАТИТУ А У ЖИТЕЛІВ ЗАКАРПАТСЬКОЇ ОБЛАСТІ
}

\author{
Ужгородський національний університет, Україна
}

Гепатит А належить до найпоширеніших вірусних хвороб печінки у всьому світі. Реальну картину серопозитивності гепатиту А можна встановити при дослідженні наявності імуноглобулінів класу $G$ до вірусу серед дорослого населення.

Мета роботи - встановити реальну поширеність серопозитивності ГА методом виявлення anti-HAV IgG та співвідношення жовтяничних фрорм захворювання до стертих, атипових, безжовтяничних у жителів Закарпатської області.

Пацієнти і методи. Дослідження наявності antiHAV IgG проводилось у 262 дорослих осіб, пацієнтів обласних лікувальних закладів. Цілеспрямоване опитування на наявність в анамнезі захворювання з ознаками жовтяниці проведено у 203 хворих Обласної клінічної інфекційної лікарні.

Результати. Антитіла IgG до вірусу гепатиту $A$ виявлено у 77,48 \% обстежених. Частота знаходження їх залежала від віку та місця проживання і не залежала від статі: найменшою була у віці від 18 до 29 років і найбільшою у віці 60 років і більше $(p<0,001) ; y$ жителів м. Ужгорода вірогідно меншою за жителів інших міст, сільських населених пунктів і жителів Закарпатської області в цілому ( $p<0,01-0,001)$.

При цілеспрямованому опитуванні хворих на наявність у минулому захворювання, яке б супроводжувалося жовтяницею, виявлено всього 9 осіб, що становить 4,43\%.

Висновки. Отримані результати свідчать про значну серопозитивність гепатиту А серед жителів Закарпатській області. Офріційно реєструється менше десятої частини хворих, які перенесли дане захворювання. Серед дорослого населення переважають безжовтяничні фрорми гепатиту А. Частота виявлення анамнестичних антитіл до гепатиту А залежить від віку та місця проживання обстежених.

Ключові слова: гепатит $A$, імуноглобулін $G$ до вірусу гепатиту $A$.

Гепатит А (ГА) належить до найпоширеніших вірусних хвороб печінки у всьому світі [1]. За останні роки в
Україні відбулося суттєве зменшення захворюваності на цю недугу, однак епідеміологічна ситуація продовжує залишатися напруженою [2]. Особливо складною вона $€$ у Закарпатській області, де інтенсивні показники захворюваності на 100 тис. населення значно перевершують загальнодержавні $[3,4]$. Варто нагадати, що переважно реєструються жовтяничні форми хвороби, які складають лише десяту частину; безжовтяничні та інапарантні форми, як правило, не розпізнаються і не реєструються [5]. Переважно хворіють діти у віці 5-14 років. У них домінують також безжовтяничні форми. 3 наростанням віку ГА перебігає тяжче, частіше з типовою клінічною картиною $[1,5]$. У США 25 \% захворювань припадає на осіб до 20 років [6].

Реальну картину поширеності серопозитивності ГА можливо встановити лише при дослідженні наявності імуноглобулінів класу G до вірусу (anti-HAV IgG) серед дорослого населення [7]. Останні починають виявлятися в період розпалу захворювання і зберігаються протягом всього життя, забезпечуючи стійкий імунітет [1]. Частота виявлення anti-HAV IgG великою мірою залежить від віку особи та інтенсивності епідемічного процесу і коливається в широких межах: від 10-37 \% у розвинутих країнах до майже 100 \% в окремих країнах 3 незадовільними санітарними умовами та у жителів деяких островів південної частини Тихого океану $[8,9]$. Подібні дослідження у межах Закарпатської області не проводились, і судити про реальну поширеність маркерів ГА серед ії̈ жителів та інтенсивність епідемічного процесу в цьому регіоні є доволі проблематично.

Мета роботи - встановити реальну поширеність серопозитивності ГА методом виявлення anti-HAV IgG та співвідношення жовтяничних фрорм захворювання до стертих, атипових, безжовтяничних у жителів Закарпатської області.

\section{Пацієнти і методи}

Для досягнення мети нами досліджено наявність antiHAV IgG серед пацієнтів Обласної клінічної інфекційної лікарні (ОКІЛ), ендокринологічного відділення Закарпатської обласної клінічної лікарні ім. А. Новака (ЗОкЛ), За- 
карпатського обласного Центру з профілактики та боротьби зі СНІДом (ЗЦПБ СНІД), Закарпатської обласної станції переливання крові (ЗОСПК). Визначення anti-HAV IgG проводилося методом ІФА з використанням «ВГА-IgGБЕСТ. Тест-система імуноферментна для виявлення антитіл класу IgG до вірусу гепатиту А» ТОВ «БЕСТ ДІАГНОСТИК». Паралельно проведено цілеспрямоване опитування хворих ОКІЛ на наявність в анамнезі захворювання, яке б перебігало із жовтяницею. Пацієнти, яких ушпиталювали 3 підозрою на гепатити, до групи опитаних не включалися. Залучення таких хворих до обстеження здійснювалося за їх добровільної письмової згоди. Усі отримані цифррові результати обробляли на комп'ютері за програмою Statistica 6 i Exel XP із встановленням відмінності за критерієм Стьюдента.

\section{Результати досліджень та їх обговорення}

Дослідження наявності anti-HAV IgG проводилось у 262 дорослих осіб, пацієнтів обласних закладів, у тому числі: ЗОКЛ ім. А. Новака - 27 осіб, з них чоловіків 12, жінок 15, віком від 22 до 72 років, середній вік $(49,26 \pm 2,99)$ років; ЗОСПК - 41 особа, чоловіків 23, жінок 18, віком від 19 до 62 років, середній вік $(39,98 \pm 2,09)$ років; ЗЦПБ СНІД - 50 осіб, чоловіків 34, жінок 16, віком від 23 до 59 років, середній вік $(38,24 \pm 1,12)$ років; ОКІЛ - 144 особи, чоловіків 72, жінок 72, віком від 19 до 70 років, середній вік $(44,22 \pm 1,18)$ років.

Цілеспрямоване опитування на наявність в анамнезі захворювання з ознаками жовтяниці проведено у 203 хворих ОКІЛ, віком від 19 до 80 років, середній вік $(41,25 \pm 1,06)$ років. Отримані результати представлені у таблиці 1.

Таблиця 1

Виявлення anti-HAV IgG у пацієнтів лікувальних установ Закарпатської області

\begin{tabular}{|c|c|c|c|c|}
\hline \multirow{2}{*}{ Заклад } & \multirow{2}{*}{ Число обстежених (n) } & \multirow{2}{*}{$\begin{array}{c}\text { Середній вік (років), } \\
\text { M } \pm m\end{array}$} & \multicolumn{2}{|c|}{ Частота виявлення anti-HAV IgG } \\
\hline & & & абс. к-сть & $\%$ \\
\hline ЗОКЛ ім. А. Новака & 27 & $49,26 \pm 2,99^{3,4}$ & 26 & $96,30 * 1,2$ \\
\hline ЗОСПК & 41 & $39,98 \pm 2,09$ & 31 & 75,61 \\
\hline ЗЦПБ СНІД & 50 & $38,24 \pm 1,12$ & 42 & 84,00 \\
\hline ОКІЛ & 144 & $44,22 \pm 1,18^{4}$ & 104 & 72,22 \\
\hline Всі обстежені & 262 & $42,93 \pm 0,84^{4}$ & 203 & 77,48 \\
\hline
\end{tabular}

Примітки: * - вірогідна відмінність частоти виявлення anti-HAV IgG від групи «Всі обстежені»; ${ }^{1}-3$ пацієнтами ОКІЛ (р<0,01); ${ }^{2}$-3 пацієнтами ЗОСПК ( $\left.<<0,05\right) ;{ }^{3}$ - вірогідна відмінність між середнім віком пацієнтів ЗОСпК $(p<0,02) ;{ }^{4}-$ вірогідна відмінність між середнім віком пацієнтів ЗЦПБ СНІД $(p<0,05-0,01)$.

Серед всіх обстежених хворих антитіла класу $\mathrm{G}$ до HAV виявлено у 203 осіб, що становить 77,48 \%. Отже, ми можемо стверджувати, що більше трьох четвертих дорослого населення Закарпатської області перенесла у минулому ГА, внаслідок якого у них залишився імунітет.

Найчастіше виявлялись антитіла до ГА серед пацієнтів ендокринологічного відділення ЗОКЛ ім. А. Новака. В останніх вони знайдені значно частіше за хворих ОКІЛ, 3ОСПК та всіх хворих області ( $<<0,05-0,01)$. Найрідше anti-HAV IgG були виявлені у хворих ОКІЛ. У них вони мали статистично вагому відмінність з пацієнтами ЗОКЛ ім. А. Новака $(p<0,01)$ і виражену тенденцію відмінності 3 пацієнтами ЗЦПБ СНІД ( $p=0,09)$. Обстежені особи із ЗЦПБ СНІД мали найменший середній вік, менший за пацієнтів ЗОКЛ ім. А. Новака та всіх обстежених $(p<0,02)$. У пацієнтів ендокринологічного відділення ЗОКЛ ім. А. Новака середній вік був більшим за вік пацієнтів ЗОСПК та ЗЦПБ СНІД $(p<0,02)$.

Враховуючи те, що у Закарпатській області частка хворих на ГА великою мірою залежить від віку [10], ми провели аналіз частоти виявлення anti-HAV IgG серед різних вікових категорій. Отримані результати наведено у таблиці 2.

Наведені у таблиці дані підтверджують залежність частоти виявлення anti-HAV IgG від віку. Вона збільшується 3 його наростанням. Найменша частка хворих 3 виявленими anti-HAV IgG припадає на вікову категорію від 18 до 29 років. Вона вірогідно менша за всі групи, окрім «30-39 років» ( $p<0,01-0,001)$. Найбільша частка пацієнтів з anti-HAV IgG припадає на вікову категорію «60 і більше років». Вона вірогідно більша за групи «18-29 років», «30-39 років» $\mathrm{i}$ «Всі обстежені» $(\mathrm{p}<0,01-$ $0,001)$.

Між часткою дорослого населення серед пацієнтів ОКІЛ і обласними показниками виявлено різницю майже у 10 \% [10]. Така відмінність може бути пов'язана з особливостями епідемічного процесу в різних населених пунктах. 3 метою їх уточнення було проведено аналіз частоти виявлення anti-HAV IgG в окремих містах та районах області. Результати представлені в таблиці 3. 
ОРИГІНАЛЬНІ ДОСЛІДЖЕННЯ

Таблиця 2

Частота виявлення anti-HAV IgG у хворих різного віку

\begin{tabular}{|l|c|c|c|}
\hline \multirow{2}{*}{ Вікова група } & \multirow{2}{*}{ Число обстежених (n) } & \multicolumn{2}{c|}{ Частота anti-HAV IgG } \\
\cline { 3 - 4 } & & aбс. к-сть & 54,00 * \\
\hline $18-29$ років & 50 & 27 & 70,77 \\
\hline $30-39$ років & 65 & 46 & $83,87^{1}$ \\
\hline $40-49$ років & 62 & 32 & $82,98^{1}$ \\
\hline $50-59$ років & 47 & 37 & $97,37^{* 1,2}$ \\
\hline Всі обстежені & 38 & 203 & 77,48 \\
\hline
\end{tabular}

Примітки: * - вірогідна різниця 3 групою «Всі обстежені» $\left(\right.$ р<0,01-0,001); ${ }^{1}-3$ групою «18-29 років» $(\mathrm{p}<0,01-0,001)$; 2 - 3 групою «30-39 років» $(\mathrm{p}<0,01)$.

Таблиця 3

Частота виявлення anti-HAV IgG та вік пацієнтів обласних лікувальних закладів Закарпаття залежно від місця проживання

\begin{tabular}{|l|c|c|c|c|}
\hline \multirow{2}{*}{ Населені пункти } & \multirow{2}{*}{ Кількість обстежених (n) } & Вік (років), & \multicolumn{2}{c|}{ Чacтота anti-HAV IgG } \\
\cline { 3 - 6 } & & абс. к-сть & \% \\
\hline Ужгород & 78 & $41,63 \pm 1,57$ & 47 & 60,26 \\
\hline Ужгородський район & 20 & $44,30 \pm 3,18$ & 15 & 75,00 \\
\hline Міста Закарпатської області & 78 & $42,87 \pm 1,50$ & 65 & $83,33^{1}$ \\
\hline Села Закарпатської області & 86 & $43,85 \pm 1,45$ & 75 & $87,21^{1,2}$ \\
\hline Жителі Закарпатської області & 262 & $42,93 \pm 0,84$ & 203 & $77,48^{1}$ \\
\hline
\end{tabular}

Примітки: ${ }^{1}$ - вірогідна відмінність у частоті виявлення anti-HAV IgG серед жителів м. Ужгорода $(p<0,01-0,001) ;{ }^{2}-$ серед жителів Закарпатської області $(p<0,05)$.

Як випливає з даних наведеної таблиці, частота виявлення anti-HAV IgG у населення Закарпатської області залежить від місця проживання. У жителів м. Ужгорода вона вірогідно менша за інші міста області та села ( $p<0,01-0,001)$. У жителів сільської місцевості частота виявлення anti-HAV IgG найбільша, має статистично вагомі відмінності від жителів м. Ужгорода та середніх показників по області ( $p<0,05-0,01)$. Вірогідних відмінностей у середньому віці жителів різних населених пунктів області не виявлено.

При проведенні аналізу частоти виявлення IgG до вірусу ГА у жителів Закарпатської області залежно від статі статистично вагомих відмінностей не виявлено ( $>0,05)$. За даними літератури, у всіх вікових категоріях хворих на ГА превалюють особи чоловічої статі [1].

Враховуючи отримані нами результати частоти виявлення anti-HAV IgG у жителів Закарпатської області, стверджувати про вірогідні відмінності поширеності перенесеного у минулому ГА серед пацієнтів різних обласних лікувальних установ доволі проблематично. У пацієнтів ЗОКл ім. А. Новака вірогідно був більший середній вік і менша частка жителів м. Ужгорода за паці- єнтів ОКІЛ ( $p<0,01-0,001)$, а у пацієнтів 3ОСПК - менший середній вік $(p<0,05)$.

При цілеспрямованому опитуванні 203 пацієнтів ОКІЛ на наявність у минулому захворювання, яке б супроводжувалося жовтяницею, виявлено всього 9 осіб, що становить 4,43 \%. При порівнянні середнього віку всіх обстежених жителів Закарпатської області на наявність anti-HAV IgG і опитаних на можливість захворювання з ознаками жовтяниці вагомої відмінності не було $(p>0,05)$.

Припустимо, що всі виявлені при опитуванні особи перенесли саме ГА. Враховуючи, що anti-HAV IgG серед жителів Закарпатської області виявлено у 77,48 \%, співвідношення жовтяничних фрорм до безжовтяничних у жителів Закарпатської області становитиме 1:17,5. За даними літератури, безжовтяничні та інапарантні форми превалюють над жовтяничними у 2-10 разів. У дитячому віці переважають безжовтяничні фрорми, у дорослому - жовтяничні $[1,7]$. Співвідношення манісрестних фрорм до стертих у дорослому віці становить 5:1 [9]. При постійно високій активності епідемічного процесу на осіб дитячого віку припадає більшість випадків ГА [9]. Не 
зважаючи на постійно високі показники захворюваності на дану недугу в області, серед пацієнтів ОКІЛ діти становлять близько половини, а по області - більше половини [10]. Слід врахувати, що серед дорослого населення у віці до 30 років виявлено найбільшу кількість хворих, госпіталізованих в ОКІЛ 3 діагнозом ГА (53,52 \%) [10], a anti-HAV IgG встановлено у 54,0 \% обстежених. Різниця у частоті виявлення anti-HAV IgG між віковими категоріями до 30 років і 60 й старші становить 43,37 \%. Ми можемо припустити, що інорікування останніх відбулося у дорослому віці. Таким чином, для дорослих і для дітей співвідношення жовтяничних форм до безжовтяничних не повинно мати суттєвих відмінностей. Подібне твердження суперечить даним літератури [1, 7].

При проведенні найпростіших розрахунків щорічних інтенсивних показників захворюваності на 100 тис. населення нами встановлено, що в Закарпатській області він повинен становити 1805 випадків, у м. Ужгороді 1447, у селах - 1988. За останні роки найбільший інтенсивний показник зареєстровано у 2013 р. і становив 132,05 випадків [10], що в 13,7 разу менше від отриманих нами розрахункових даних.

\section{Література}

1. Шиффф Ю.Р. Болезни печени по Шиффру. Вирусные гепатиты и холестатические заболевания / Ю.Р. Шифф, М.Ф. Соррел, У.С. Мэддрей: Пер. с англ. / под ред. В.Т. Ивашкина. - М.: ГЭОТАРМЕД, 2010. - 408 с.

2. Порохницький В.Г. Вірусні гепатити / В.Г. Порохницький, В.С. Топольницький. - Київ: Книга-плюс, 2010. - 480 с.

3. Когутич А.І. Клініко-епідеміологічні особливості гепатиту А у дитячого населення Закарпатської області / А.І. Когутич // Проблеми клінічної педіатрії. - 2015. - № 4. - С. 10-14.

4. Когутич А.І. Клініко-епідеміологічні особливості гепатиту А у жителів Закарпатської області / А.І. Когутич, Г.М. Коваль, Є.С. Сірчак // Гастроентерологія. - 2015. - № 3 (57). - С. 44-47.

5. Малый В.П. Гепатит А / В.П. Малый // Клиническая иммунология. Аллергология. Инфектология. - 2013. - № 1. - С. 40-49.

6. Center for Diseases Control and Prevention (CDC). Guidelines for viral hepatitis surveillance and case management. - Atlanta: GA, 2004. - P. 1-47.

\section{References}

1. Shiff, Yu.R., Sorrel, M.F., \& Meddrey, U.S. (2010). Bolezni pecheni po Shiffu. Virusnye gepatity i kholestaticheskiye zabolevaniya [Schiff's diseases of the liver. Viral hepatitis and cholestatic diseases]. Moscow: GEOTAR-Media [in Russian].

2. Porokhnytskyi, V.H., \& Topolnytskyi, V.S. (2010). Virusni hepatyty [Viral hepatitis]. Kyiv: Knyha-plius. [in Ukrainian].

\section{Висновки}

1. Серед обстежених пацієнтів обласних лікувальних установ Закарпаття у 77,48 \% виявлено антитіла класу G до вірусу ГА.

2. Частота виявлення anti-HAV IgG залежить від віку: найменша у віці від 18 до 29 років (54,00 \%); найбільша у віці 60 років і більше $(97,37 \%)$.

3. Залежно від місця проживання виявляється різна частота anti-HAV IgG: найменша у м. Ужгороді (60,26 \%), найбільша у селах області (87,21 \%).

4. Частота виявлення anti-HAV IgG не залежить від статі.

5. Всього 4,43 \% опитаних дорослих осіб серед пацієнтів ОКІЛ вказують на наявність у минулому захворювання з ознаками жовтяниці.

6. Співвідношення жовтяничних фрорм ГА до безжовтяничних серед обстежених осіб становить 1:17,5.

7. Серед обстежених осіб 43,37 \% перенесли ГА у дорослому віці.

8. ГА у дорослому віці, як і в дитячому, перебігає переважно у безжовтяничних фрормах.

9. Реальні показники захворюваності населення на 100 тис. на ГА у Закарпатській області значно перевершують офріційні дані.

7. Малый В.П. Вирусный гепатит А: клиника, диагностика, лечение / под ред. В.П. Малого, Т.И. Сологуб. - СПб: Тактик-Студио, 2013. - 104 c

8. Prevalence of infections by hepatitis $A, B, C$ and $E$ in two different socioeconomic groups of children from Santa Cruz., Bolivia / G.M. Gandolfo, G. M. Ferri, L. Conti [et.al.] // Med. Clin. (Barc). - 2003. - Vol. 120. - P. 725-727.

9. Эпидемиологические особенности гепатита А в Российской Федерации: новые аспекты старой проблемы / И.В. Шахгильдян, М.И. Михайлов, О.Н. Ершова [и др.] // Гепатологія. - 2010. - № 3, - C. 24-31.

10. Когутич А.І. Клініко-епідеміологічні особливості гепатиту А у дорослого населення Закарпатської області / А.І. Когутич // Проблеми клінічної педіатрії. - 2015. - № 3. - С. 95-98.

3. Kohutych, A.I. (2015). Kliniko-epidemiolohichni osoblyvosti hepatytu A u dytiachoho naselennia Zakarpatskoi oblasti [Clinical and epidemiological features of hepatitis $A$ in children population of Transcarpathian region]. Problemy klinichnoi pediatrii - Problems of Clinical Pediatrics, 4, 10-14 [in Ukrainian].

4. Kohutych, A.I., Koval, H.M., \& Sirchak, Ie.S. (2015). Klinikoepidemiolohichni osoblyvosti hepatytu A u zhyteliv Zakarpatskoi oblasti 
[Clinical and epidemiological features of hepatitis A among residents of the Transcarpathian region]. Hastroenterolohiia-Gastoenterology, 3 (57), 44-47 [in Ukrainian].

5. Malyy, V.P. (2013). Gepatit A [Hepatitis A]. Klinicheskaya immunologiya. Allergologiya. Infektologiya - Clinical Immunological. Allergology. Infectiology, 1, 40-49 [in Russian]

6. Guidelines for viral hepatitis surveillance and case managemen: Centers for Diseases Control and Preventiom (CDC). (2004). Atlanta: GA.

7. Malyy, V.P., \& Sologub, T.I. (Eds.). (2013). Virusnyy gepatit A: klinika, diagnostika, lecheniye [Viral hepatitis A: clinic, diagnosis, treatment]. Saint-Petersburg: Taktik-Studio [in Russian].

8. Gandolfo, G.M., Ferri, G.M., Conti, L., Antenucci, A., Marrone, R., Frasca, A.M., \& Vitelli, G. (2003). Prevalence of infections by hepatitis

\section{MODERN REALITIES OF HEPATITIS A IN THE TRANSCARPATHIAN REGION}

A. I. Kohutych, A. A. Halamba

Uzhhorod National University, Ukraine

SUMMARY. Hepatitis A belongs to the most common liver diseases in the world. The real picture of the prevalence of hepatitis A may be distinguished only in the study of the presence of immunoglobulin $G$ towards virus among adults.

The aim of the work - to establish the real prevalence of hepatitis $A$ using the method of detecting anti-HAV IgG and the ratio of icteric forms of the diseases to erased, atypical, anicteric forms in the residents of the Transcarpathian region.

Patients and methods. Study of available anti-HAVIgG was conducted in 262 adults, patients of regional medical institutions. Targeted surveys on a history of the disease with symptoms of jaundice were conducted in 203 patients within regional clinical infectious diseases hospital.

Results. Antibody to hepatitis A was detected in $77.48 \%$ of patients. The frequency of detection of immunoglobulin $G$ virus depended on the age and place of residence and did not depend on sex, the lowest were aged 18 to 29 years and maximum 60 years of age or more $(p<0.001)$; in the residents of the city Uzhgorod were significantly less than residents of other cities, villages and residents of the Transcarpathian region as a whole
$A, B, C$ and $E$ in two different socioeconomic groups of children from Santa Cruz., Bolivia. Med. Clin. (Barc.). 120, 725-727.

9. Shakhgildyan, I.V., Mikhaylov, M.I., Ershova, O.N., Hukhlovich, P.A., Lytkina, I.N., Shulakova, N.I., ... \& Yasinsky, A.A. (2010). Epidemiologicheskiye osobennosti gepatita A v Rossiyskoy Federatsii: novyye aspekty staroy problemy [Epidemiological features of hepatitis $A$ in the Russian Federation: new aspects of the old problem]. Gepatologiya - Gepatology, 3, 24-31 [in Russian].

10. Kohutych, A.I. (2015). Kliniko-epidemiolohichni osoblyvosti hepatytu A u dorosloho naselennia Zakarpatskoi oblasti [Clinical and epidemiological features of hepatitis A in adults of Transcarpathian region]. Problemy klinichnoi pediatrii - Problems of Clinical Pediatrics, 3, 95-98 [in Ukrainian].

$(p<0,01-0,001)$. In the targeted survey patients were asked for the presence of disease in the past, which would be accompanied by jaundice, found only in 9 people, which is $4.43 \%$.

Conclusions. The results show a significant spread of hepatitis A among residents of the Transcarpathian region. Officially registered less than in the tenth of the patients who had the disease. Among the adult population anicteric forms of hepatitis $A$ are dominant. The frequency of anamnestic antibodies to hepatitis depends on the age and place of residence.

Key words: hepatitis $A$; immunoglobulin $G$ to hepatitis A.

Відомості про авторів:

Когутич А.І. - канд. мед. н., доцент кафр. мікробіології, вірусології та імунології з курсом інфекційних хвороб, Ужгородський національний університет; a.kohutych@i. ua.

Галамба А.А. - канд. мед. н., асистент каф. мікробіології, вірусології та імунології з курсом інсрекційних хвороб, Ужгородський національний університет; ondi@list.ru.

Information about authors:

Kohutych A.I. - Candidate of Medicine, Associate Professor of Microbiology, Virology and Immunology with the Course of Infectious Diseases Department, Uzhhorod National University; a.kohutych@i.ua.

Halamba A.A. - Candidate of Medicine, Assistant Professor of Microbiology, Virology and Immunology with the Course of Infectious Diseases Department, Uzhhorod National University; ondi@list.ru.

Конфолікт інтересів: немає.

Authors have no conflict of interest to declare.

Отримано 12.04.2017 p. 